\title{
Rumah Singgah Kemah Berkah Sebagai Wadah Penginjilan Dan Penerapan Diakonia Transformatif GKII Di Wilayah Batulicin
}

\author{
Fajar Gumelar ${ }^{1 *}$, Hengki Wijaya ${ }^{2}$, Ezra Tari ${ }^{3}$ \\ Sekolah Tinggi Filsafat jaffray Makassar ${ }^{12}$, Institut Agama Kristen Negeri \\ Kupang ${ }^{3}$ \\ fajargumelar21298@gmail.com
}

\begin{abstract}
The study of this paper originated from the author's anxiety about the appropriate method of training church members. The author tries to provide a new perspective in the formation of new members of the congregation in the form of transformative deacons. The author offers another way of evangelizing and developing a deacon, namely, a shelter for camps. The author uses a descriptive approach to narrating the facts in the field. Data is collected, reduced and then analyzed so that conclusions are drawn from the facts found. The result was that the halfway house had become a place to preach the gospel in the interior of Mount Meratus. This tent house is a learning space for children to know Christ. A halfway house is a place for children to be guided with skills and independence in various daily activities to become human beings with integrity. The facts found in the field show that there are still many children who come from Christian families who do not understand life as a good Christian. The halfway house, the blessed tent, is present not only as a place for learning for children but for parents as well-a halfway house to help children attend. Children are invited to help others in need.
\end{abstract}

\section{Keywords: Halfway House, Evangelism, Transformative Diaconia}

\begin{abstract}
Abstrak: Kajian tulisan ini berawal dari kegelisahan penulis mengenai metode yang tepat dalam pembinaan warga jemaat. Penulis berusaha memberi perspektif baru dalam pembinaan warga jemaat yang baru dalam bentuk diakonia transformatif. Penulis menawarkan cara lain dalam penginjilan dan pengembangan diakonia yakni rumah singgah kemah. Penulis menggunakan pendekatan dekrriptif untuk menarasikan fakta yang ada di lapangan. Data dikumpulkan, direduksi kemudian dianalisis sehingga ditarik kesimpulan dari fakta yang ditemukan. Hasil yang ditemukan adalah rumah singgah telah menjadi tempat mewartakan injil di pedalaman gunung Meratus. Rumah kemah ini menjadi ruang belajar anak-anak untuk mengenal Kristus. Rumah singgah adalah tempat anak-anak dibimbing keterampilan, kemandirian dalam berbagai kegiatan sehari-hari dengan tujuan supaya menjadi manusia yang berintegritas. Kenyataan ditemukan di lapangan memperlihatkan bahwa masih bayak anak yang berasal dari keluarga Kristen belum memahami hidup sebagai orang Kristen yang baik. Rumah singgah kemah berkah hadir tidak hanya sebagai wadah belajar anak-anak tetapi orang tua juga. Rumah singgah membantu anak dapat madiri. Anak-anak diajak untuk membantu orang lain dalam kekurangan.
\end{abstract}

Kata Kunci: Rumah Singgah, Penginjilan, Diakonia Transformatif

$\begin{array}{llll}\text { Article History : } & \text { Received: 20-10-2020 Accepted: 14-12-2020 }\end{array}$




\section{Pendahuluan}

Gereja tidak menunjuk kepada gedung tetapi kepada kumpulan atau persekutuan orang percaya itu sendiri, yaitu setiap orang yang dipanggil dari yang gelap ke terang. Sebagai lembaga milik Allah gereja memiliki tugas dan panggilan untuk menyatakan dan menyampaikan berita sukacita tentang kerajaan dan karya Allah yang transenden di tengah-tengah dunia yang profan. Gereja sebagai tubuh Kristus membangun iklim saling peduli, saling menolong, saling menopang dan saling berbagi di antara sesama anggota jemaat. Tugas Gereja dari segi koinonia adalah melaksanakan kegiatan ibadah (worship) yang berperan merefleksikan kekudusan persekutuan. ${ }^{1}$ Dengan kata lain, gereja seyogyanya menyatakan kebenaran tentang Anak Manusia yang datang menyelamatkan ciptaan. ${ }^{2}$

Dalam menjalankan tugas dan panggilan tersebut gereja tidak luput dari berbagai macam tantangan dan pergumulan. Namun demikian tidak berarti bahwa gereja harus lari dari panggilan. Panggilan adalah panggilan ilahi, misterius, bangkit dari rahmat Tuhan, bukan dari manusia. ${ }^{3}$ Justru di tengah-tengah tantangan dan pergumulan gereja harus tetap bersukacita dan semakin giat melaksanakan tugas dan panggilan tersebut. Itulah sebabnya sangat penting bagi setiap umat Allah untuk mengerti dan memahami dengan benar tugas gereja, yaitu yang pertama melaksanakan misi, mewartakan Injil dan bersosial. Kedua, tekun berdoa, sebagai ciri dari kehidupan yang bergantung pada Allah. ${ }^{4}$ Gereja perlu terlibat dalam transformasi masyarakat, terutama memihak orang miskin dan tertindas. ${ }^{5}$ Fokus utama dalam latihan adalaha cara melakukan dialog dan memainkan peran sebagai orang Kristen dalam proses pengambilan keputusan. Dalam program pelatihan, anggota dari profesi terlibat dalam suatu pekerjaan sesuai dengan bidang masing-masing. Jenis pekerjaan dikumpulkan dalam satu kelompok dan mengerjakan strategi dan identifikasi masalah. ${ }^{6}$

William Carey (1761-1834) disebut sebagai bapa Pekabar Injil Modern menggunakan cara penginjilan dengan bekerja sebagai tukang sepatu. ${ }^{7}$ Paradigma gagasan misi menekankan sifat misionaris dari gereja lokal, kebutuhan akan pergerakan antara gereja. ${ }^{8}$ Pemberitaan injil lintas budaya terhadap perempuan Samaria merupakan teladan yang bisa dipakai pada saat kini. Cara menginjil dengan bersahabat ini dapat

\footnotetext{
${ }^{1}$ Darlin Elfri Sinaga, "Pengaruh Implementasi Tugas Panggilan Gereja Terhadap Pertumbuhan Iman Warga Jemaat Antardenominasi Di Kota Pematangsiantar Tahun 2020," Jurnal Theologia Forum STFT Surya Nusantara 8, no. 2 (October 9, 2020): 43, http://jurnalstftsunus.ac.id/index.php/stft/article/view/49/49.

${ }^{2}$ Malcolm Brownlee, Tugas Manusia Dalam Dunia Milik Tuhan: Dasar Theologis Bagi Pekerjaan Orang Kristen Dalam Masyarakat (Jakarta: BPK Gunung Mulia, 2004), 101.

${ }^{3}$ Cosmin Santi, "Vocation and Spiritual Qualities of Priest, Canon Condition for the Effective Pastoral Missionary," Teologia 61 (2014): 138-156.

4 Junihot M. Simanjuntak, “Belajar Sebagai Identitas Dan Tugas Gereja,” Jurnal Jaffray 16, no. 1 (March 17, 2018): 1.

5 Jerry Pillay, "The Church as a Transformation and Change Agent," HTS Teologiese Studies / Theological Studies 73, no. 3 (May 22, 2017): 1-12.

${ }^{6}$ Peter Christofides and Piet Meiring, "The Rediscovery of the Role of the Laity in the Mission of the Church - with Reference to the Baptist Union of Southern Africa (BUSA)," Verbum et Ecclesia 33, no. 1 (2012): 1-9.

${ }^{7}$ Junior Natan Silalahi, "Paulus Sang Entrepreneur: Pembuat Tenda Sebagai Jembatan Penginjilan,” Visio Dei: Jurnal Teologi Kristen 1, no. 1 (2019): 1-18.

${ }^{8}$ Kirsteen Kim, "Together towards Life and the Mission Studies Curriculum," International Review of Mission 104, no. 1 (April 1, 2015): 98-117, http://doi.wiley.com/10.1111/irom.12081.
} 
dipakai sebagai salah satu cara untuk melakukan penginjilan. ${ }^{9}$ Gereja berfungsi sesuai dengan rencana Allah jika hidup sebagai banyak anggota dengan satu tubuh yang saling memperlengkapi. ${ }^{10}$

Tujuan rumah singgah adalah untuk memberikan proses belajar yang wajar dengan memberi pelatihan dasar bagi keluarga-keluarga kurang mampu. Sehingga anakanak dapat belajar secara mandiri yang didampingi oleh sukarelawan yang mendukung dari berbagai aspek, baik jasmani maupun rohani. ${ }^{11}$ Keinginan pengguna rumah singgah adalah interaksi sosial eksklusif dengan kelompok yang tertarik untuk bertemu orang baru. Ada dua konsep rumah singgah yang menggunakan kemah sebagai wadahnya yakni; pertama, menempatkan tempat perkemahan untuk berteduh di lingkungan luar ruangan untuk memberikan kesan kesendirian untuk melakukan relaksasi. Kedua, Fakta bahwa motif berkemah bervariasi yakni, sesuai dengan tingkat pengalaman. ${ }^{12}$

Rumah singgah kemah didesain tertutup yang dapat dihuni, aman,nyaman dan sehat. Modularitas dan koneksi sederhana antara komponen yang berbeda menjamin kemudahan transportasi, perakitan dan pemeliharaan oleh masyarakat lokal tanpa alat khusus. ${ }^{13}$ Rumah Singgah dapat melakukan suatu pendekatan community based dan street based di dalamnya ada kegiatan pemberdayaan. Pemberdayaan mencakup masalah sosial anak dengan meningkatkan kapabilitas diri melalui pendidikan. ${ }^{14}$ Problematika ini yang membuat penulis untuk melakukan kajian tentang pelayanan di rumah singgah Kemah Berkah di kota Batulicin, Kalimantan Selatan. Tujuan kajian ini adalah pertama, menemukan wadah pemberdayaan jemaat di GKII Batulicin. Kedua, menawarkan rumah singgah berkah sebagai wadah pembinaan jemaat. Ketiga, mengefektifkan rumah singgah berkah.

\section{Metode Penelitian}

Metode kualitatif. Peneliti mengungkap makna dari berbagai keadaan nyata yang sedang terjadi dalam kehidupan sosial. Berdasarkan pendekatan tersebut, penelitian ini menggunakan penelitian sosial deskriptif. ${ }^{15}$ Metode deskriptif digunakan untuk membentangkan informasi mengenai permasalahan yang sedang

\footnotetext{
${ }^{9}$ Hannas and Rinawaty, "Menerapkan Model Penginjilan Pada Masa Kini," Kurios: Jurnal Teologi dan Pendidikan Agama Kristen 5, no. 2 (October 31, 2019): 175-189, https://sttpb.ac.id/ejournal/index.php/kurios/article/view/118.

${ }^{10}$ Ramona Vera Amiman, "Penatalanan Gereja DI Bidang Misi Sebagai Kontribusi Bagi Pelaksanaan Misi Gereja," Missio Ecclesiae 7, no. 2 (October 2018): 185, https://jurnal.i3batu.ac.id/index.php/me/article/view/85.

11 David Martinus Gulo et al., "Pelayanan Rumah Singgah Sebagai Media Misi Gereja : Pelayanan Rumah Singgah GBI Tanjung Balai Karimun," Real Didache: Jurnal Teologi dan Pendidikan Agama Kirsten 4, no. 1 (2019): 102-109.

12 Mathilde Skov Kristensen et al., "Motives for Shelter Camping. A Survey-Study on Motivational Differences across Group Composition and Experience Level," Journal of Outdoor Recreation and Tourism 33 (March 1, 2021) 100333: 1-9, https://linkinghub.elsevier.com/retrieve/pii/S2213078020300578.

13 Graziano Salvalai et al., "Architecture for Refugees, Resilience Shelter Project: A Case Study Using Recycled Skis,” in Procedia Engineering, vol. 180 (Elsevier Ltd, 2017), 1110-1120.

${ }^{14}$ Fikriryandi Putra, Dessy Hasanah, and Eva Nuriyah, "Pemberdayaan Anak Jalanan Di Rumah Singgah," Share : Social Work Journal 5, no. 1 (July 27, 2015): 5-6, http://journal.unpad.ac.id/share/article/view/13118.

15 Daniel Fajar Panuntun and Eunike Paramita, "Kaderisasi Pemimpin Melalui Pemuridan Kontekstual Sebagai Jawaban Dari Krisis Keteladanan Kepemimpinan,” Kinaa: Jurnal Kepemimpinan kristen dan Pemberdayaan Jemaat 1, no. 1 (2020): 1-15, http://kinaa.iakntoraja.ac.id/index.php/ojsdatakinaa/article/view/1.
} 
diteliti. Serta penjelasan mengenai sebuah fenomena yang penelitian. ${ }^{16}$ Peneliti terlibat langsung dalam penelitian melayani di Rumah Singgah Kemah Berkah dan pedalaman Kalimantan Selatan selama kurang lebih 6 bulan. Penulis berinteraksi dengan pendeta Wangyu, pendeta Novitripena, dan Mega Ratie serta anggota jemaat GKII Siloam Tarakan. Penelitian ini dimaksudkan untuk mengeksplorasi suatu fakta sosial, kemudian dideskripsikan sesuai dengan masalah yang ingin diselesaikan. ${ }^{17}$ Analisis data dipakai dengan menemukan dan mengatur ulang secara terperinci, membentangkan ke dalam unit-unit, melakukan sintesis, reduksi data, dan ringkasan. ${ }^{18}$

Peneliti mengumpulkan data dari pengamatan dan wawancara. Kedua, menyeleksi data yang didapatkan. Ketiga, mengoreksi, memperluas dan menampilkan fakta yang ada. Keempat, memindahkan kasus berikutnya. Enam, mencari pola lintas kasus $^{19}$

\section{Hasil dan Pembahasan}

\section{Sejarah Berdirinya Rumah Singgah Kemah Berkah}

Pada tahun 2011 GKII Siloam-Tarakan mengutus Wangyu sebangai evangelis ke kota Batulicin, Kalimantan Selatan sebagai penginjil untuk memenangkan jiwa orangorang Banjar. Pendekatan dilakukan lewat berbagai macam kegiatan seperti pelatihan sepak bola, berkebun dan usaha asuransi. Namun sampai pada tahun 2015 belum ada jiwa seorang pun yang dimenangkan bagi Kristus. Rasa sedih, jenuh dan putus asa mulai dirasakan, sehingga muncul pula niatan hati saudara Wangyu untuk kembali ke kampung halaman. Sebelum mengambil tindakan untuk pulang, saudara Wangyu bersama istri mengambil waktu untuk berdoa dan berpuasa, meminta petunjuk dari Tuhan.

Tuhan pun memberi jawaban atas doa mereka. Pada tanggal 21 Januari 2015 seorang anak bernama Desi datang ke kediaman keluarga saudara Wangyu dan memohon untuk diizinkan tinggal bersama mereka, sambil dia menyelesaikan pendidikannya. Dia pun diizinkan untuk tinggal bersama mereka. Desi merupakan masyarakat asli Juhu yang datang ke kota Batulicin untuk melanjutkan pendidikan. Dia tinggal di panti asuhan yang dikelola oleh salah satu gereja di Batulicin - saudara Wangyu bersama istri juga sempat bergereja di gereja tersebut karena belum ada persekutuan yang berhasil terbentuk oleh pelayanan mereka. Namun kemudian ada masalah yang terjadi di panti asuhan yang membuat Desi keluar dan memutuskan untuk tinggal bersama keluarga saudara Wangyu, yang dikenalnya dalam lingkup persekutuan gereja yang mengelola panti asuhan tersebut. Kedatangan Desi membuat saudara Wangyu bersama istri memutuskan tetap bertahan di Batulicin.

Setahun kemudian Desi membawa tiga orang anak lain untuk tinggal bersama keluarga saudara Wangyu. Walaupun sempat ragu, namun saudara Wangyu bersama istri tetap menerima mereka. Seiring waktu jumlah anak yang datang semakin

\footnotetext{
16 Sonny Eli Zaluchu, "Strategi Penelitian Kualitatif Dan Kuantitatif Di Dalam Penelitian Agama," Evangelikal: Jurnal Teologi Injili dan Pembinaan Warga Jemaat 4, no. 1 (January 31, 2020): 28, , https://journal.sttsimpson.ac.id/index.php/EJTI/article/view/167.

${ }_{17}$ Mohammad Mulyadi, "Penelitian Kuantitatif Dan Kualitatif Serta Pemikiran Dasar

Menggabungkannya," Jurnal Studi Komunikasi Dan Media 15, no. 1 (2011): 127-138, http://jurnal.kominfo.go.id/index.php/jskm/article/download/52/49.

${ }^{18}$ Hengki Wijaya, Analisis Data Kualitatif Ilmu Pendidikan Teologi (Makassar: Sekolah Tinggi Theologia Jaffray Makassar, 2018), 52-53.

${ }^{19}$ Firman, Analisis Data Dalam Penelitian Kualitatif, 2018, 10, https://www.researchgate.net/publication/328675958_Analisis_Data_dalam_Penelitian_Kualitatif
} 
bertambah. Saudara Wangyu bersama istri akhirnya melihat jawaban Tuhan atas doa mereka, bahwa mereka harus memulai pelayanan dari anak-anak yang datang kepada mereka untuk kemudian mereka juga dapat menjangkau keluarga dari anak-anak tersebut. Muncullah ide untuk menjadikan kediaman mereka sebagai rumah singgah. Di rumah singgah tersebut anak-anak disekolahkan serta dibina dan dibimbing dalam pengajaran iman Kristen.

Ketika keberadaan rumah singgah ini disampaikan kepada gereja pengutus, sempat terjadi ketegangan sehingga gereja pengutus menolak untuk mendukung operasional rumah singgah tersebut. Hal ini tidak membuat saudara Wangyu bersama istri menjadi putus asa. Mereka tetap setia menjalankan visi Allah bagi mereka, walaupun harus mengorbankan harta benda yang mereka miliki. Suatu kali diadakan pertemuan di gereja pengutus dimana di dalamnya turut hadir pula saudara Wangyu. Dalam pertemuan itu dia memberikan penjelasan dan presentasi tentang rumah singgah sebagai peluang penginjilan. Gereja pengutus akhirnya memahami dan menangkap visi Allah sehingga pada tahun 2017 gereja pengutus mulai memberi dukungannya.

Sampai saat ini rumah singgah di Kota Batulicin yang dinamakan rumah singgah Kemah Berkah tetap berdiri dengan jumlah anak asuh sebanyak 23 orang, yang sebagian besarnya berasal dari daerah-daerah di pedalaman Gunung Meratus. ${ }^{20}$

\section{Rumah Singgah Kemah Berkah Sebagai Wadah Pemberdayaan Jemaat dalam Pelayanan}

Data anak asuh rumah singgah Kemah Berkah tahun 2019 menunjukkan bahwa mayoritas bukan Kristen. Sebagian besar diantaranya berasal dari latar belakang agama suku yaitu Kaharingan. Menyikapi hal ini rumah singgah Kemah Berkah menjalankan fungsinya sebagai wadah penyampaian Injil kepada anak-anak asuh. Penyampaian Injil ini tidak mendapatkan pertentangan dari pihak orang tua, sebab sebelumnya masingmasing anak asuh telah membacakan surat pernyataan di hadapan orang tua mereka yang salah satu poinnya adalah bersedia dan siap untuk dibimbing dalam pengajaran iman Kristen sesuai asas sinode GKII.

Adapun penyampaian Injil ini tidak mendapatkan pertentangan dari pihak orang tua, sebab sebelumnya masing-masing anak asuh telah membacakan surat pernyataan di hadapan orang tua mereka yang salah satu poinnya adalah bersedia dan siap untuk dibimbing dalam pengajaran iman Kristen sesuai asas sinode GKII. Rumah singgah Kemah Berkah sebagai wadah pemberdayaan jemaat tidak hanya menjadikan anak-anak asuh sebagai sasaran tetapi juga para orang tua mereka. Melalui kesaksian anak kepada orang tua - secara verbal maupun dalam sikap dan tindakan - orang tua dapat digugah dan dibawa dalam pengenalan akan Kristus.

Pemberdayaan akan sedikit mudah dilakukan ketika seorang pemimpin sudah lebih dahulu memliki kemampuan dan karunia tersebut. Prinsipnya, gereja tidak dapat berkembang tanpa sebuah kegiatan misi yang diterapkan oleh gereja. ${ }^{21}$ Seorang pemimpin gereja memerlukan perhimpunan.

Keberhasilan pemberdayaan ekonomi berjamaah terletak pada motivasi dan orientasi aktor itu sendiri, di mana Gereja diharapkan untuk bertarung secara serius. ${ }^{22}$ Walaupun jumlah jemaat sangat terbatas, tetapi pelayanan dilaksanakan di rumah

20 Wangyu, Wawancara Oleh Penulis 31 Juli, 2019.

${ }^{21}$ Eben Munthe, "Mengoptimalkan Karunia Dalam Jemaat Untuk Melakukan Misi Amanat Agung

Di Era 4.0," EPIGRAPHE: Jurnal Teologi dan Pelayanan Kristiani 3 (2019): 133.

22 Tongam Nababan, "Increasing Economic Welfare of Church Congregation: A Concept of Empowerment," Jurnal Ekonomi dan Studi Pembangunan (JESP) 9, no. 1 (2017): 113-121. 
singgah maupun di masyarakat tetap dapat berjalan secara efektif dan efisien. Alih-alih menjadi kelemahan, jumlah jemaat yang sedikit justru menjadi kekuatan terbaik, oleh karena pengajaran dan pelatihan yang diberikan dapat terlaksana secara maksimal dan mendalam, sehingga pelaksanaan pelayanan penginjilan oleh jemaat pun dapat berjalan dengan baik.

\section{Rumah Singgah Kemah Berkah Sebagai Wadah Pemberdayaan Jemaat Dalam Penerapan Diakonia Transformatif}

Rumah singgah Kemah Berkah berjalan dalam visi: Membentuk kepribadian anak-anak menjadi pribadi yang takut akan Tuhan, cerdas dan mandiri. Kehadiran rumah singgah Kemah Berkah bukan hanya sekadar menampung anak-anak untuk bersekolah saja, tetapi menyiapkan mereka untuk menjadi penerus bangsa dan penerus gereja yang bermartabat dan siap menghadapi tantangan perkembangan zaman.

Model diakonia yang diterapkan melalui rumah singgah Kemah Berkah pada dasarnya merupakan model diakonia transformatif. Diakonia transformatif ialah jasa yang mencelikkan mata yang tunanetra serta memampukan kaki yang lesu menjadi kokoh berjalan sendiri. ${ }^{23}$ Artinya bahwa pelayanan yang dilakukan tidak semata-mata menolong orang yang dalam kondisi terpuruk, tertindas, terabaikan, miskin dan menderita tetapi lebih lagi, mencari akar permasalahan yang menjadi pemicu keadaan atau kondisi tersebut serta menolong mereka untuk dapat lepas darinya. Menghadirkan diakonia yang transformatif berarti membantu warga keluar dari kemiskinan. ${ }^{24}$

Anak-anak asuh yang dibina di rumah singgah Kemah Berkah merupakan anakanak yang berasal dari desa Muara Urie dan desa-desa kecil lain di pedalaman Gunung Meratus, Kalimantan Selatan. Adapun masyarakat di daerah-daerah tersebut dikekang dan diikat oleh masalah kemiskinan, kesenjangan sosial, masalah moral serta masalah pendidikan. Pengurus rumah singgah Kemah Berkah melihat masalah ini dan mengidentifikasi bahwa akar dari pergumulan atau persoalan yang dihadapi masyarakat adalah kurangnya pengajaran, pembinaan, pendidikan dan yang utama adalah penerimaan akan Kristus. Untuk itu rumah singgah Kemah Berkah hadir untuk menolong masyarakat lepas dari hal-hal tersebut melalui kegiatan pengajaran, pembinaan, pendidikan dan penginjilan kepada generasi muda yang adalah generasi penerus.

Pengurus rumah singgah memberikan bimbingan moral, keterampilan, kemandirian dan kerohanian dalam berbagai kegiatan sehari-hari kepada para anak asuh dengan tujuan supaya mereka menjadi manusia yang berintegritas, bermartabat, dan hidup takut akan Tuhan. Tidak lepas sampai disitu anak-anak asuh pun disekolahkan dengan tujuan supaya mereka lepas dari jerat kebodohan, sehingga di kemudian hari mereka menjadi generasi penerus bangsa yang sigap terhadap neokolonialisme dan neo-imperialisme dalam persaingan global. Bimbingan dan pendidikan yang diberikan kepada putra-putri daerah Gunung Meratus adalah upaya untuk

${ }^{23}$ Yosef Purnama Widyatmadja, Yesus Dan Wong Cilik: Praksis Diakonia Transformatif Dan Teologi Rakyat Di Indonesia (Jakarta: BPK Gunung Mulia, 2010), 44.

24 Jozef M. N. Hehanussa, "Pelayanan Diakonia Yang Transformatif: Tuntutan Atau Tantangan," Gema Teologi 36, no. 1 (April 2012): 127-138, https://journaltheo.ukdw.ac.id/index.php/gema/article/download/139/130/. 
membangkitkan masyarakat dari kelumpuhan dan ketidakmampuan untuk mengubah realitas. ${ }^{25}$

Rumah singgah Kemah Berkah sebagai penerapan diakonia transformatif oleh sinode GKII didasarkan atas karya agung Allah yang memperhatikan seluruh aspek eksistensi manusia, meliputi roh dan fisik. ${ }^{26}$ Dengan demikian gereja telah menyadari identitasnya bukan hanya sebagai pusat kegiatan ritualistik tetapi juga bagian dari masyarakat plural yang mempunyai tugas untuk mewujudkan negara yang berperikemanusiaan, adil dan makmur. Hal ini senada dengan yang dijelaskan oleh Zakaria J. Ngelow, bahwa gereja bukan hanya sebatas organisasi atau lembaga ritual keagamaan, tetapi sebagai alat Allah memberi kesaksian megenai Injil Kerajaan Allah. Oleh sebab itu, gereja dipanggil melaksanakan pembaharuan atau transformasi dalam kehidupan manusia, baik pribadi maupun masyarakat. ${ }^{27}$ Hadirnya rumah singgah Kemah Berkah telah mewariskan semangat bagi gereja untuk dapat semakin giat menjalankan tugas dan panggilannya dalam dunia yang fana: bukan hanya sebatas kontemplasi tetapi juga terwujud nyata dalam aksi.

Untuk membangun rumah singgah tidak semudah yang orang lain pikirkan atau saksikan di tempat-tempat lain. Kami harus melalui proses yang tidak mudah. Apalagi anak-anak yang dibina bermacam-macam karakter dan kepribadiannya. Tentu sangat menguras energi. Hanya oleh anugerah Tuhan kami masih ada sampai sekarang. Tantangan terbesar yang kami hadapi adalah diri kami sendiri. Terkadang muncul perasaan jenuh, bosan dan kecewa. Tetapi lewat semua ini karakter dan kepribadian kami pun dibentuk, sehingga pelayanan dari tahun 2011-2019 dapat terus berjalan dan kami melayani dengan apa yang ada pada kami. Kami percaya segala kekurangan dan keterbatasan kami Tuhan yang akan mencukupkan dan tambahkan.

GKII Siloam-Tarakan yang setia terus mendukung kami baik dalam hal dana, doa maupun tenaga. Bagi kami GKII Siloam-Tarakan adalah orang tua yang sangat peduli dengan kami, mulai dari pengutusan sampai sekarang. Mereka terus komitmen membantu kami. Harapan kami kedepan kiranya rumah singgah ini menjadi alat atau salah satu metode penginjilan untuk suku-suku terabaikan khususnya suku Dayak Meratus yang beragama Kaharingan. Dan kiranya rumah singgah ini menjadi rumah singgah percontohan untuk GKII.

Adapun rumah singgah ini juga adalah gereja, rumah doa, rumah untuk membina dan mendidik anak-anak supaya mereka menerima Tuhan Yesus, berkarakter dan hidup mandiri. Pengurus perlu jelaskan kepada anak-anak asuh bahwa melalui rumah singgah mereka semua bisa mandiri dan bukan hanya menunggu orang lain membantu, bahkan bukan tidak mungkin, rumah singgah inilah yang akan membantu orang yang lain yang kekurangan. ${ }^{28}$ Melayani Tuhan itu belajar melaksanakan apa yang Tuhan inginkan, bukan kemauan manusia semata. Anak-anak boleh ada dengan kami bukan karena keinginan kami, tetapi rencana Tuhan. Tuhan yang menghendaki, Tuhan yang mencukupkan kebutuhan, Tuhan juga yang menambah jumlah. Mendidik dan membina anak-anak setiap hari serta berinteraksi dengan mereka memberi banyak pelajaran buat saya. Belajar arti kesabaran. Belajar untuk mengorbankan apa yang saya

\footnotetext{
${ }^{25}$ Widyatmadja, Yesus Dan Wong Cilik: Praksis Diakonia Transformatif Dan Teologi Rakyat Di Indonesia, 50-51.

${ }^{26}$ Herry Susanto, “Gereja Sebagai Umat Allah Dan Rekan Negara,” Jurnal Jaffray 17, no. 1 (April 2, 2019): 35, http://ojs.sttjaffray.ac.id/index.php/JJV71/index.

27 Zakaria J. Ngelow, "Turut Membina Indonesia Sebagai Rumah Bersama - Peran Gereja Dalam Politik Di Indonesia," Jurnal Jaffray 12, no. 2 (2014): 214-284.

${ }^{28}$ Wangyu, Wawancara Oleh Penulis 31 Juli.
} 
anggap berharga untuk mendapatkan yang lebih berharga dari Tuhan, dan masih banyak pelajaran-pelajaran yang lain.

Dari banyaknya pengalaman dengan anak-anak di sini dan dari pengalaman mempelajari latar belakang mereka, satu hal mimpi saya yang saya minta kepada Tuhan. Bahwa seperti apa pun anak-anak ini saat ini, suatu saat saya ingin melihat dan menyaksikan mereka menjadi orang-orang yang berhasil, takut akan Tuhan dan menjadi berkat bagi keluarga mereka. Tetapi kembali lagi Tuhan yang punya pekerjaan yang memampukan kami melewatinya. Harapan saya, ada hamba Tuhan yang benar-benar punya hati pelayanan dan punya hati mengasihi anak-anak di sini untuk bergabung bersama melayani anak-anak ini. Kami meyakini bahwa anak-anak. ${ }^{29}$

Mega Ratie, salah satu staf di rumah singgah. Ia datang ke sini awal tahun 2018 dan sampai sekarang masih tetap mengabdi di rumah singgah Kemah Berkah. Ada banyak suka duka yang ia alami dalam pelayanan di rumah singgah ini.. Ia masih muda, baru lulus tahun 2017. Secara fisik saya juga kecil, tidak beda jauh dengan fisik anakanak asuh di rumah singgah. Anak-anak yang dilayani sering tidak menghargai dan meremehkan. Walaupun begitu, ia belajar tentang arti sebuah pelayanan.

Walaupun banyak tantangan namun Ia merasa senang berada disini karena banyak pelajaran yang saya dapatkan. Saya turut dibentuk disini. Awalnya ingin pulang karena merasa tidak mampu. Tetapi kemudian saya menyadari bahwa saya ada disini karena kehendak Tuhan. Pelayanan saya disini bukan berdasarkan kekuatan saya tetapi karena Tuhan. Dia yang telah memilih saya, Dia juga yang akan senantiasa memampukan saya dalam pelayanan di tempat ini.

Harapan untuk anak-anak di rumah singgah ini adalah supaya mereka semua bisa belajar dengan baik dan mereka bisa menggapai cita-cita. Ia berharap ada orangorang yang tergerak untuk mendukung dan mensponsori anak-anak di rumah singgah. Ia percaya Tuhan akan senantiasa mencukupkan segala keperluan anak-anak di sini bahkan kami semua. ${ }^{30}$

\section{Kesimpulan}

Pelayanan bukan berbicara mengenai apa yang akan diterima melainkan apa yang sudah diterima yaitu keselamatan dalam Kristus. Rumah singgah Kemah Berkah telah menunjukkan hal ini. Visi Tuhan berhasil ditangkap dan misi mulai dijalankan untuk memenangkan daerah-daerah di pedalaman Gunung Meratus. Rumah singgah Kemah Berkah merupakan tempat wadah pemberdayaan jemaat yang diperuntukkan bukan hanya anak-anak asuh melainkan orang tua juga. Di rumah singgah inilah pengajaran dan pelatihan diberikan secara maksimal dan mendalam. Pelaksanaan pelayanan di rumah ini dapat membantu orang yang kekurangan. Di rumah ini, anakanak dilatih belajar dengan baik agar dapat menggapai cita-cita. Melalui tulisan ini penulis mengajak gereja, orang-orang percaya untuk dapat ambil bagian dalam pelayanan yang mulia ini, dengan cara memberikan dukungan baik melalui doa, dana maupun tenaga.

${ }^{29}$ Novitripena, Wawancara Oleh Penulis 3 Agustus, 2019.

30 Mega Ratie, Wawancara Oleh Penulis 3 Agustus, 2019. 


\section{Referensi}

Amiman, Ramona Vera. "Penatalanan Gereja DI Bidang Misi Sebagai Kontribusi Bagi Pelaksanaan Misi Gereja." Missio Ecclesiae 7, no. 2 (October 2018): 185. https://jurnal.i3batu.ac.id/index.php/me/article/view/85.

Brownlee, Malcolm. Tugas Manusia Dalam Dunia Milik Tuhan: Dasar Theologis Bagi Pekerjaan Orang Kristen Dalam Masyarakat. Jakarta: BPK Gunung Mulia, 2004.

Christofides, Peter, and Piet Meiring. "The Rediscovery of the Role of the Laity in the Mission of the Church - with Reference to the Baptist Union of Southern Africa (BUSA)." Verbum et Ecclesia 33, no. 1 (2012): 1-9.

Firman. Analisis Data Dalam Penelitian Kualitatif, 2018.

https://www.researchgate.net/publication/328675958_Analisis_Data_dalam_Penelitian_K ualitatif

Gidion. "Efektifitas Kepemimpinan Yang Memberdayakan Dalam Meningkatkan Pertumbuhan Gereja Di Gereja Jemaat Kristen Indonesia Maranatha Ungaran." Shiftkey: Jurnal Teologi dan Pengembangan Pelayanan 8, no. 1 (2018): 16-33.

Gulo, David Martinus, Fransiskus Irwan Widjaja, Daniel Ginting, and Renson Siahaan. "Pelayanan Rumah Singgah Sebagai Media Misi Gereja : Pelayanan Rumah Singgah GBI Tanjung Balai Karimun." Real Didache: Jurnal Teologi dan Pendidikan Agama Kirsten 4, no. 1 (2019): 102-109.

Hannas, and Rinawaty. "Menerapkan Model Penginjilan Pada Masa Kini." Kurios: Jurnal Teologi dan Pendidikan Agama Kristen 5, no. 2 (October 31, 2019): 175-189. https://sttpb.ac.id/e-journal/index.php/kurios/article/view/118.

Hehanussa, Jozef M. N. "Pelayanan Diakonia Yang Transformatif: Tuntutan Atau Tantangan." Gema Teologi 36, no. 1 (April 2012): 127-138. https://journaltheo.ukdw.ac.id/index.php/gema/article/download/139/130/.

Kim, Kirsteen. "Together towards Life and the Mission Studies Curriculum." International Review of Mission 104, no. 1 (April 1, 2015): 98-117. http://doi.wiley.com/10.1111/irom.12081.

Kristensen, Mathilde Skov, Jan Arvidsen, Karsten Elmose-Østerlund, and Evald Bundgård Iversen. "Motives for Shelter Camping. A Survey-Study on Motivational Differences across Group Composition and Experience Level." Journal of Outdoor Recreation and Tourism 33 (March 1, 2021)100333: 1-9. https://linkinghub.elsevier.com/retrieve/pii/S2213078020300578.

Mulyadi, Mohammad. "Penelitian Kuantitatif Dan Kualitatif Serta Pemikiran Dasar Menggabungkannya." Jurnal Studi Komunikasi Dan Media 15, no. 1 (2011): 127-138. http://jurnal.kominfo.go.id/index.php/jskm/article/download/52/49.

Munthe, Eben. "Mengoptimalkan Karunia Dalam Jemaat Untuk Melakukan Misi Amanat Agung Di Era 4.0." EPIGRAPHE: Jurnal Teologi dan Pelayanan Kristiani 3 (2019): 133-141.

Nababan, Tongam. "Increasing Economic Welfare of Church Congregation: A Concept of Empowerment." Jurnal Ekonomi dan Studi Pembangunan (JESP) 9, no. 1 (2017): 113-121.

Ngelow, Zakaria J. “Turut Membina Indonesia Sebagai Rumah Bersama - Peran Gereja Dalam Politik Di Indonesia." Jurnal Jaffray 12, no. 2 (2014): 214-284.

Novitripena. Wawancara Oleh Penulis 3 Agustus, 2019.

Panuntun, Daniel Fajar, and Eunike Paramita. "Kaderisasi Pemimpin Melalui Pemuridan Kontekstual Sebagai Jawaban Dari Krisis Keteladanan Kepemimpinan.” Kinaa: Junral Kepemimpinan kristen dan Pemberdayaan Jemaat 1, no. 1 (2020): 1-15. 
http://kinaa.iakn-toraja.ac.id/index.php/ojsdatakinaa/article/view/1.

Pillay, Jerry. "The Church as a Transformation and Change Agent." HTS Teologiese Studies / Theological Studies 73, no. 3 (May 22, 2017): 1-12.

Putra, Fikriryandi, Dessy Hasanah, and Eva Nuriyah. "Pemberdayaan Anak Jalanan Di Rumah Singgah." Share : Social Work Journal 5, no. 1 (July 27, 2015): 5-6. Accessed October 19, 2020. http://journal.unpad.ac.id/share/article/view/13118.

Ratie, Mega. Wawancara Oleh Penulis 3 Agustus, 2019.

Salvalai, Graziano, Marco Imperadori, Federico Lumina, Elisa Mutti, and Ilaria Polese. "Architecture for Refugees, Resilience Shelter Project: A Case Study Using Recycled Skis." In Procedia Engineering, 180:1110-1120. Elsevier Ltd, 2017.

Santi, Cosmin. "Vocation and Spiritual Qualities of Priest, Canon Condition for the Effective Pastoral Missionary." Teologia 61 (2014): 138-156.

Silalahi, Junior Natan. "Paulus Sang Entrepreneur: Pembuat Tenda Sebagai Jembatan Penginjilan.” Visio Dei: Jurnal Teologi Kristen 1, no. 1 (2019): 1-18.

Simanjuntak, Junihot M. "Belajar Sebagai Identitas Dan Tugas Gereja." Jurnal Jaffray 16, no. 1 (March 17, 2018): 1-24.

Sinaga, Darlin Elfri. “Pengaruh Implementasi Tugas Panggilan Gereja Terhadap Pertumbuhan Iman Warga Jemaat Antardenominasi Di Kota Pematangsiantar Tahun 2020." Jurnal Theologia Forum STFT Surya Nusantara 8, no. 2 (October 9, 2020): 61-69. http://jurnalstftsunus.ac.id/index.php/stft/article/view/49/49.

Susanto, Herry. “Gereja Sebagai Umat Allah Dan Rekan Negara." Jurnal Jaffray 17, no. 1 (April 2, 2019): 127-138. http://ojs.sttjaffray.ac.id/index.php/JJV71/index.

Wangyu. Wawancara Oleh Penulis 31 Juli, 2019.

Widyatmadja, Yosef Purnama. Yesus Dan Wong Cilik: Praksis Diakonia Transformatif Dan Teologi Rakyat Di Indonesia. Jakarta: BPK Gunung Mulia, 2010.

Wijaya, Hengki. Analisis Data Kualitatif Ilmu Pendidikan Teologi. Makassar: Sekolah Tinggi Theologia Jaffray Makassar, 2018.

Zaluchu, Sonny Eli. "Strategi Penelitian Kualitatif Dan Kuantitatif Di Dalam Penelitian Agama." Evangelikal: Jurnal Teologi Injili dan Pembinaan Warga Jemaat 4, no. 1 (January 31, 2020): 28-38.

https://journal.sttsimpson.ac.id/index.php/EJTI/article/view/167. 